\title{
E74-Like Factor (ELF3) and Leptin, a Novel Loop Between Obesity and Inflammation Perpetuating a Pro-Catabolic State in Cartilage
}

\author{
Javier Conde Miguel Otero $^{b} \quad$ Morena Scotece $^{a}$ Vanessa Abella ${ }^{a}$ \\ Rodolfo Gómez ${ }^{c}$ Verónica López ${ }^{\mathrm{a}}$ Jesús Pino ${ }^{\mathrm{d}}$ Antonio Mera ${ }^{\mathrm{e}}$ \\ Mary B. Goldring ${ }^{b}$ Oreste Gualillo
}

aSERGAS, Santiago University Clinical Hospital, NEIRID Lab (NeuroEndocrine Interaction in Rheumatology and Inflammatory Diseases), Institute of Medical Research (IDIS), Building C, Level-2, Santiago de Compostela, Spain, bOrthopaedic Soft Tissue Research Program, The Hospital for Special Surgery, and Department of Cell and Developmental Biology, Weill Cornell Medical College, New York, NY, USA, cMusculoskeletal Pathology Laboratory, Institute IDIS, Santiago University Clinical Hospital, Santiago de Compostela, 'SERGAS, Santiago University Clinical Hospital, Division of Orthopaedic Surgery and Traumatology, Santiago de Compostela, eSERGAS (Servizo Galego de Saude), Division of Rheumatology, Santiago University Clinical Hospital, Santiago de Compostela, Spain

\section{Key Words}

Adipokines • Transcriptional control • Inflammation • Cartilage

\begin{abstract}
Background/Aims: The E74-like factor 3 (ELF3) is an inflammatory mediator that participates in cartilage destruction in osteoarthritis. Leptin and other adipokines negatively impact articular cartilage, triggering catabolic and inflammatory responses in chondrocytes. Here, we investigated whether leptin induces ELF3 expression in chondrocytes and the signaling pathway involved in this process. Methods: We determined mRNA and protein levels of ELF3 by RT-qPCR and Western blotting using cultured human primary chondrocytes and the human T/C-28a2 chondrocyte cell line. Further, we measured luciferase activities of different reporter constructs, and we assessed the contribution of leptin to the induction of ELF3 mRNA by knocking down hLEPR gene expression using siRNA technology. Results: Leptin synergizes with IL-1 $\beta$ in inducing ELF3 expression in chondrocytes. We also found that PI3K, p38, and JAK2 signaling pathways are at play in the leptin-driven induction of ELF3. Moreover, we confirm the participation of NFKB in the leptin/IL-1 $\beta$ synergistic induction of ELF3. Conclusion: Here we show, for the first time, the regulation of ELF3 expression by leptin, suggesting that this transcription factor likely mediates the inflammatory responses triggered by leptin in articular chondrocytes.

Oreste Gualillo

and Javier Conde

Santiago University Clinical Hospital, NEIRID Lab, NeuroEndocrine Interactions in Rheumatology and Inflammatory Diseases, Research Area, Laboratory $n^{\circ}$ 9, Building $C$, Santiago de Compostela (Spain)

Tel.+34+981+950905, E-Mail oreste.gualillo@sergas.es, jcondearanda@gmail.com
\end{abstract}

KARGER 


\section{Cellular Physiology Cell Physiol Biochem 2018;45:2401-2410 and Biochemistry Published onIIne: IVarch 16, $2018 \quad \begin{aligned} & \text { DOI: 10.1159/000488227 } 2018 \text { The Author(s). Published by S. Karger AG, Basel } \\ & \text { www.karger.com/cpb }\end{aligned}$ \\ Conde et al.: Leptin Mediates ELF3 in Cartilage, Linking Obesity and Inflammation}

\section{Introduction}

Articular cartilage is a highly specialized connective tissue that lines bone surfaces, and provides low-friction and hydrodynamic load-bearing surfaces in articulating joints. In adult articular cartilage, chondrocytes are responsible for the turnover and maintenance of the collagens, proteoglycans and other molecules of the extracellular matrix (ECM). Chondrocytes exhibit aberrant behaviour during cartilage degenerative diseases, with increased ECM degradation and inadequate repair processes [1]. Several factors are involved in the pathogenesis of cartilage degenerative diseases, and stress- and inflammation-induced signaling pathways are known to contribute to the destruction of articular cartilage in both osteoarthritis (OA) and rheumatoid arthritis (RA) [2,3]. As a model to understand these mechanisms, chondrocytes cultured in vitro with interleukin (IL)-1 and tumor necrosis factor (TNF) $\alpha$ show decreased expression of a number of genes associated with the differentiated chondrocyte phenotype, including type II collagen [4]. These signaling pathways also upregulate the expression of a number of genes encoding cartilage-d egradative factors, including MMP13, COX2 or NOS2, via the induction and activation of downstream transcription factors such as NF- $\kappa \mathrm{B}, \mathrm{C} / \mathrm{EBP} \beta, \mathrm{AP}-1$ family members, and ETS factors [5-7].

The ETS transcription factors constitute a family of at least 30 members involved in the regulation of differentiation, cell proliferation, and ECM remodelling in both physiological and pathological conditions [6, 8]. The ETS family member, E74-like factor 3 (ELF3), also known as ESX, ESE1, ERT, or JEN, is expressed normally in epithelial tissues in physiological conditions [8], but it is induced by inflammatory stimuli in a number of tissues and cell types, including RA and OA cartilage and synovium [6]. In turn, ELF3 controls and mediates inflammatory actions via transcriptional control of genes such as NOS2, COX2 and LCN2 [911]. ELF3 displays roles in cartilage catabolism and suppression of anabolic gene expression in chondrocytes, acting as a repressor of type II collagen gene (COL2A1) promoter activity, both directly binding to the promoter [12] and disrupting the Sox9-CBP/p300 interaction [13], but also as a transactivator of the metalloproteinase (MMP) 13 promoter via a proximal evolutionarily conserved ETS binding site (EBS) [14].

Obesity is one of the major risk factors for joint degenerative diseases, affecting joint tissues both biochemically and mechanically, and involving locally produced as well as systemically secreted factors [15]. Obesity is characterized by the accumulation of dysfunctional adipose tissue secreting a plethora of regulatory factors, generally called adipokines. The relationship between adipokines and cartilage degeneration is now widely recognized $[5,15,16]$ and leptin, the forerunner of the adipokine superfamily, can trigger proinflammatory and catabolic cascades in articular chondrocytes by inducing the expression of IL-8, NOS2, MMP3, MMP13 and VCAM-1 [5, 17-19]. Moreover, leptin is also able to increase the expression of ADAMTS-4, -5 and -9 in human chondrocytes and this effect involves the activation of MAPK and NF- $\mathrm{BB}$ signaling pathways [20]. All together, these data suggest the participation of leptin in chondrocyte-mediated ECM degradation.

To gain further insight into the signaling pathways and factors utilized by leptin in articular chondrocytes, we aimed to determine whether leptin induces ELF3 in chondrocytes. To this end, we defined the signaling events involved in the leptin activation of the ELF3 promoter and expression, with special focus on the contribution of the NF- $\mathrm{BB}$ signaling cascade, which is required for ELF3 expression, as reported previously [6, 9].

\section{Materials and Methods}

\section{Reagents}

All culture reagents were purchased from Sigma (Missouri, USA) except Dulbecco's modified Eagle's medium/Ham's F12 (DMEM/Ham's F12) medium and the trypsin-ethylenediaminetetraacetic acid (Lonza, Switzerland). For RT-qPCR analysis, First Strand reverse transcription kit, SYBR-green qPCR master mix, and primers were purchased from SABiosciences (MD, USA). Nucleospin kits for RNA and protein isolation were 


\section{Cellular Physiology Cell Physiol Biochem 2018;45:2401-2410 and Biochemistry Published onIIne: IVarch 16, 2018 \begin{tabular}{l|l} 
DOI: 10.1159/000488227 & $\begin{array}{l}\text { C } 2018 \text { The Author(s). Published by S. Karger AG, Basel } \\
\text { www.karger.com/cpb }\end{array}$
\end{tabular} \\ Conde et al.: Leptin Mediates ELF3 in Cartilage, Linking Obesity and Inflammation}

from Machery-Nagel (Germany). Human recombinant leptin, human recombinant IL-1 $\beta$, dexamethasone, tyrphostin AG490 (JAK2 inhibitor), SB203580 (p38 inhibitor) and LY294002 (PI3K-AKT inhibitor) were from Sigma. For transfection assays, Lipofectamine Reagent, PLUS Reagent and Opti-MEM I Reduced Serum Media were purchased from Invitrogen (CA, USA), and the Luciferase Assay (Cat. \#E1500) and Renilla Luciferase Assay (Cat. \#E2810) systems were from Promega (Wisconsin, USA). For silencing experiments, the Accell SMART pool E-008015-00-0005 human leptin receptor (LEPR; NM_001003680, 5 nmol) siRNA oligonucleotides, and the Accell siRNA Delivery Media were purchased from Thermo Scientific (Illinois, USA).

\section{Cell culture conditions and treatments}

The human juvenile costal chondrocyte cell line T/C-28a2 was cultured as previously described [21]. For experiments, cells were seeded in 6-well plates in DMEM/Ham's F12 supplemented with 10\% fetal bovine serum (FBS), L-glutamine, and antibiotics (50 units $/ \mathrm{ml}$ penicillin and $50 \mu \mathrm{g} / \mathrm{ml}$ streptomycin).

Human primary chondrocytes were isolated and cultured, as described [14, 22, 23], from articular cartilage samples obtained from knee joints of patients undergoing total joint replacement (with patient consent and permission from the local ethics committee). For experimental purposes, passage 1 primary chondrocytes were seeded at a density of $2.5 \times 10^{4}$ cells $/ \mathrm{cm}^{2}$ in DMEM/F-12 supplemented with $10 \%$ FBS. All experiments involving stimulation with inflammatory cytokines and/or adipokines were performed in serum-free conditions.

Cells were treated with human IL-1 $\beta$, human leptin, and dexamethasone for the indicated times and concentrations. Specific pharmacological inhibitors were added 1 hour before stimulation at the indicated concentrations. All treatments were performed in at least three independent experiments.

\section{RNA isolation and real-time reverse transcription-polymerase chain reaction (RT-qPCR)}

mRNA levels were determined using SYBR-green based quantitative PCR (qPCR). Briefly, RNA was extracted using a NucleoSpin kit according to the manufacturer's instructions, and reverse-transcribed (RT) using a SABiosciences First Strand Kit. After the RT reaction, qPCR analysis was performed with a SABiosciences Master Mix and specific PCR primers for human ELF3 (82 bp, PPH09786B, reference position 2868, GenBank accession no. NM_004433.4); human GAPDH (175 bp, PPH00150E, reference position 1287-1310, GenBank accession no. NM_002046.3). Amplification efficiencies were calculated for all primers utilizing serial dilutions of the pooled cDNA samples. The data were calculated, using the comparative $(\Delta \Delta \mathrm{Ct})$ method and the MxPro software (Stratagene, CA, USA), as the ratio of each gene to the expression of the housekeeping gene. Data are shown as mean \pm s.e.m (error bars) of at least three independent experiments and represented as fold-change vs. control. Melting curves were generated to ensure a single gene-specific peak, and no-template controls were included for each run and each set of primers to control for unspecific amplifications.

\section{Plasmid constructs and DNA transfection assays}

The WT and NF- KB-mutant ELF3 Luciferase promoter sequences were described previously [6, 9]. Transfection experiments were carried out in the T/C-28a2 cells, basically as described previously [14]. Briefly, cells were seeded at $2 \times 10^{5}$ cells per well in 6-well plates and transfected with a total of $400 \mathrm{ng}$ of DNA of WT or NF-KB-mutant construct and $200 \mathrm{ng}$ of Renilla luciferase reporter vector as a transfection efficiency control (Promega, Wisconsin, USA), using Lipofectamine PLUS reagents and Opti-MEM I medium containing reduced serum. At 4 hours after transfection, the medium was changed to serum-free DMEM/ Ham's F12. The cells were then treated with IL-1 $\beta(10 \mathrm{ng} / \mathrm{mL})$ or human recombinant leptin $(800 \mathrm{nM})$ for additional 20 hours. Luciferase activities were measured using the Luciferase Assay System and Renilla Luciferase Assay System, respectively, in a FLUO star BMG LABTECH luminometer (Offenburg, Germany). We also transiently transfected chondrocytes with p50 or p65 expression vectors (Addgene, MA, USA) or an empty construct (pCMV4). Transfections were performed independently at least three times.

\section{siRNA transfection}

For siRNA-mediated experiments, T/C-28a2 cells were seeded at $2 \times 10^{5}$ cells per well in 6-well plates and incubated overnight with DMEM/Ham's F12 with 10\% FBS. The medium was then changed to Accell Delivery Media containing $20 \mathrm{nM}$ of either non-targeting siRNAs or the Accell SMART pool siRNA for hLEPR. 


\section{Cellular Physiology Cell Physiol Biochem 2018;45:2401-2410

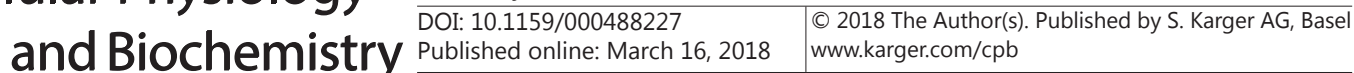 \\ Conde et al.: Leptin Mediates ELF3 in Cartilage, Linking Obesity and Inflammation}

Incubation was continued for 72 hours after siRNA tranfection, and the LEPR knockdown (KD) was verified at the mRNA and protein levels (data not shown). At $72 \mathrm{~h}$ after transfection, the cells were treated with IL-1 $\beta$ $(10 \mathrm{ng} / \mathrm{mL})$ and human recombinant leptin $(800 \mathrm{nM})$ for additional 24 hours. At $24 \mathrm{~h}$ after treatment, total RNA was isolated and ELF3 mRNA was analyzed by RT-qPCR.

\section{Western blotting analysis}

Whole cell lysates were extracted using a lysis buffer for protein extraction $(10 \mathrm{mM}$ Tris/HCl, $\mathrm{pH}$ 7.5, $5 \mathrm{mM}$ EDTA, $150 \mathrm{mM} \mathrm{NaCl}, 30 \mathrm{mM}$ sodium pyrophosphate, $50 \mathrm{mM}$ sodium fluoride, $1 \mathrm{mM}$ sodium orhtovanadate, $0.5 \%$ Triton X-100, protease inhibitor cocktail), and analyzed following immunoblotting procedures described previously $[11,16]$. Immunoblots were incubated with specific antibodies against human ELF3 (ABCAM, UK), p65 (Santa Cruz Biotechnologies, CA, USA) and IкB- $\alpha$ (Cell Signaling Technology, MA, USA) and visualized using an Immobilon Western kit (Millipore, MA, USA) and horseradish-peroxidaselabelled secondary antibody. To confirm equal loading for each sample, membranes were stripped in glycine buffer at pH 3 and reblotted with anti-actin antibody (Sigma, MO, USA) or anti-laminB1 (GeneTex, CA, USA). Autoradiographs were analyzed with an EC3 imaging system (UVP, CA, USA).

\section{Statistical analysis}

Data are reported as mean \pm S.E.M. (error bars) of at least three independent experiments. Statistical analyses were performed by ANOVA followed by unpaired $t$-test and Student-Newman-Keuls test, using the GraphPad Prism 4 software, with $p$ values $<0.05$ considered significant.

\section{Results}

Leptin induces ELF3 expression in synergism with $I L-1 \beta$

We first investigated whether leptin, alone or in combination with IL-1 $\beta$, was able to induce ELF3 expression in human primary chondrocytes and in the immortalized chondrocytes T/C28a2. As shown in Fig. $1 \mathrm{~A}, 24 \mathrm{~h}$ of stimulation with IL-1 $\beta$ significantly increased ELF3 mRNA and protein levels in human primary chondrocytes, whereas leptin alone had no significant effect. However, when the cells were treated with leptin in combination with IL-1 $\beta$, a synergistic effect was observed. We also confirmed this synergistic induction of ELF3 in the T/ C28a2 cell line (Fig. 1B).

We also determined that leptin-driven induction of ELF3 mRNA is dependent on leptin receptor long form (LEPR) expression in chondrocytes. Indeed, LEPR gene knockdown completely blunted the effect of leptin (Fig. 1C).

Fig. 1. Leptin induces ELF3 mRNA and protein expression in human chondrocytes in synergism with IL-1 $\beta$. A. ELF3 mRNA and protein expression after treatment with IL-1 $\beta$ (10 $\mathrm{ng} / \mathrm{mL}$ ) or leptin (800nM), alone or in combination, in human

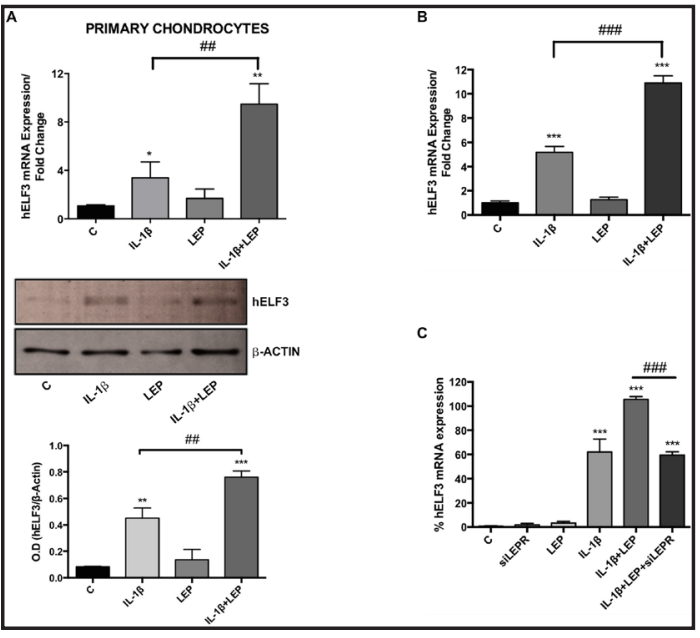
primary chondrocytes. $*, * *, * * *$ indicate $\mathrm{p}<0.05, \mathrm{p}<0.01$ and $\mathrm{p}<0.001$ vs. unstimulated control, respectively; \#\# indicates $\mathrm{p}<0.01$ vs. IL-1 $\beta$. B. ELF3 mRNA expression after treatment with IL-1 $\beta(10 \mathrm{ng} / \mathrm{mL})$ or leptin $(800 \mathrm{nM})$, or in combination in immortalized human chondrocytic cells, $\mathrm{T} / \mathrm{C} 28 \mathrm{a} 2$. ${ }^{* * *}$ indicates $\mathrm{p}<0.001$ vs. unstimulated control; \#\#\# indicates $\mathrm{p}<0.001$ vs. IL-1 $\beta$. C. ELF3 mRNA expression after treatment with IL-1 $\beta$ (10 ng/mL) or leptin (800 $\mathrm{nM}$ ), alone or in combination, or following transfection with siRNA-hLEPR $(20 \mathrm{nM})$. ${ }^{* * *}$ indicates $\mathrm{p}<0.001$ vs. unstimulated control; \#\#\# indicates $\mathrm{p}<0.001$ vs. IL-1 $\beta+L E P$. 


\section{Cellular Physiology Cell Physiol Biochem 2018;45:2401-2410 \begin{tabular}{l|l} 
and Biochemistry Publisnea onme-1VIarcn 16, 2018 & $\begin{array}{l}\text { DOI: } 2018 \text { The Author(s). Published by S. Karger AG, Basel } \\
\text { www.karger.com/cpb }\end{array}$
\end{tabular} Conde et al.: Leptin Mediates ELF3 in Cartilage, Linking Obesity and Inflammation}

Anti-inflammatory treatment decreases the induction of ELF3

To confirm the role of ELF3 as a pro-inflammatory mediator, we determined whether the antiinflammatory drug, dexamethasone, was able to interfere with the expression of ELF3 in human chondrocytes. We found that incubation of chondrocytes with dexamethasone not only inhibited the IL-1 $\beta$-driven induction of ELF3 mRNA, but also significantly decreased the expression of ELF3 when $\mathrm{T} / \mathrm{C} 28 \mathrm{a} 2$ chondrocytes were stimulated with IL-1 $\beta$ in combination with leptin (Fig. 2A-B)

Signaling cascades involved in the $I L-1 \beta$ - and leptin-driven

ELF3 gene expression and promoter transactivation

We next investigated the signaling cascade(s) involved in IL-1 $\beta$ - and leptin-driven ELF3 gene expression. As shown in Fig. 3A, IL-1 $\beta$ treatment and the combination of leptin plus IL-1 $\beta$ increased the phosphorylation of AKT, p38, and JAK2. However, leptin, by itself, only induced the phosphorylation of JAK2 (Fig. 3A).

In order to corroborate the involvement of these kinases in the induction of ELF3, we evaluated the effects of specific pharmacological inhibitors of AKT, p38, and JAK2 on ELF3 mRNA by pre-treating the T/C28a2 cells with LY294002, SB203580, or tyrphostin AG490 for 1 hour before cytokine addition. Subsequent RT-qPCR analysis revealed significantly decreased ELF3 mRNA levels in cells pre-treated with the inhibitors (Fig. 3B, C and D).

We next explored the contribution of the NF- $\mathrm{kB}$ signaling cascade to the IL-1- and leptindriven ELF3 induction. First, we observed that leptin increased the degradation of IкB- $\alpha$

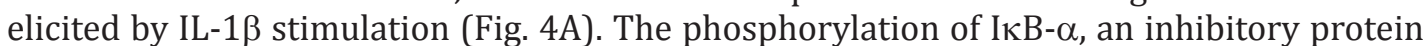
joined to NF- $\kappa B$, results in its proteosomal degradation permitting activation of NF- $\kappa B$ and translocation to the nucleus. In fact, we observed that leptin increased the translocation of

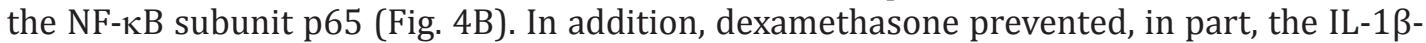
induced I $\mathrm{KB}-\alpha$ degradation (Fig. $4 \mathrm{~A}$, lower panel).

To further confirm the involvement of NF- $\mathrm{KB}$ in the induction of ELF3, we co-transfected the $\mathrm{T} / \mathrm{C}-28 \mathrm{a} 2$ cells with a luciferase reporter construct containing a wild-type proximal human ELF3 promoter sequence (pELF3) and the expression vectors for p50 and/or p65. As shown in Fig. 4C, the NF- $\mathrm{BB}$ subunit p65 and the heterodimer p65/p50 were able to significantly transactivate the ELF3 promoter. Interestingly, the inhibition of the AKT, p38, or JAK2, significantly decreased the NFKB-driven ELF3 promoter activation (Fig. 4D).

Finally, we transfected T/C28a2 chondrocytes with either the wild-type luciferase reporter construct or a mutant ELF3 promoter construct containing a defective proximal NF- $\kappa B$ binding site ( $\mathrm{p} E L F 3-m u t$ ), as described previously [6]. As expected, IL-1 $\beta$ stimulation strongly induced the wild-type ELF3 promoter transactivation, whereas leptin alone had little or no effect on the promoter activity (Fig. 4E). Consistent with the synergism between IL-1 $\beta$ and leptin in inducing ELF3 mRNA expression (Fig. 1A-B), co-stimulation with IL-1 $\beta$ and leptin synergistically activated the wild type ELF3 promoter (Fig. 4E). In agreement with previous findings [6], the ELF3 promoter activity strongly depended on the proximal NF- $\kappa B$ binding site, as shown by the lack of transactivation of the pELF3-mut construct by IL-1 $\beta$ alone or in combination with leptin (Fig. 4F). 
Fig. 3. Analysis of the signaling pathways involved in ELF3 induction. A. Analysis of the phosphorylation of AKT, p38, and JAK2 by Western blotting. Cells were treated with IL-1 $\beta(10 \mathrm{ng} /$ $\mathrm{mL})$ and leptin $(800 \mathrm{nM})$ for 30 minutes for AKT and p38 phosphorylation detection and for 5 minutes for JAK2 phosphorylation detection. B, C, D. Determination of ELF3 mRNA expression by RT-qPCR after treatment of T/C$28 \mathrm{a} 2$ cells with $\mathrm{IL}-1 \beta(10 \mathrm{ng} / \mathrm{mL})$ or leptin $(800 \mathrm{nM})$, alone or in combination, and together with. Cells were pre-treated with pharmacological inhibitors, LY204002

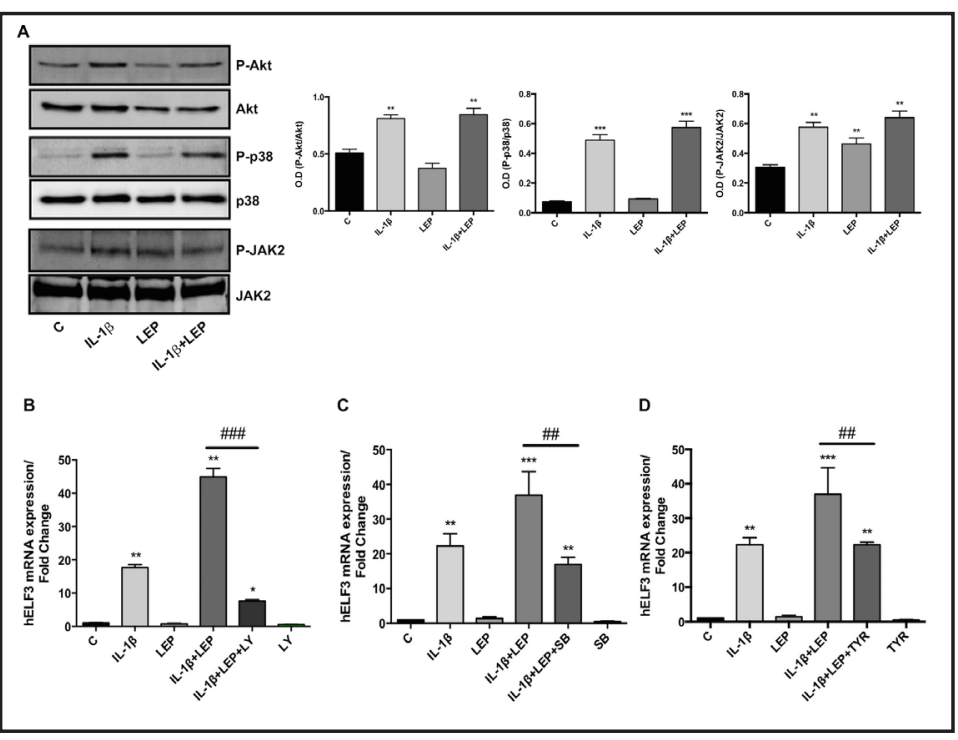
$(10 \mu \mathrm{M}), \mathrm{SB} 203580(30 \mu \mathrm{M})$, or tyrphostin AG490 $(10 \mu \mathrm{M})$, for 1 hour before cytokine challenge. * indicates $\mathrm{p}<0.05$; ${ }^{* *}$ indicates $\mathrm{p}<0.01$; ${ }^{* * *}$ indicates $p<0.001$ vs. control. \#\# indicates $p<0.01$; \#\#\# indicates $p<0.001$ vs. IL-1 $\beta+L E P$.

Fig. 4. A. Analysis of the degradation of IKB- $\alpha$ by Western blotting. Cells were pre-treated with dexamethasone $(1 \mu \mathrm{M})$ for 2 hours and then treated with IL-1 $\beta$ $(10 \mathrm{ng} / \mathrm{mL})$ and leptin $(800 \mathrm{nM})$ for 30 minutes. B. Densitometric analysis of different Western blots using nuclear extracts from cells treated with IL-1 $\beta$ (10 ng/ $\mathrm{mL}$ ) and leptin (800 nM) for 30 minutes after incubation with the antibody against NF- $\mathrm{KB}$ subunit p65 (normalized with the antibody anti-LaminB1). C. Co-transfections with Luciferase reporter constructs containing

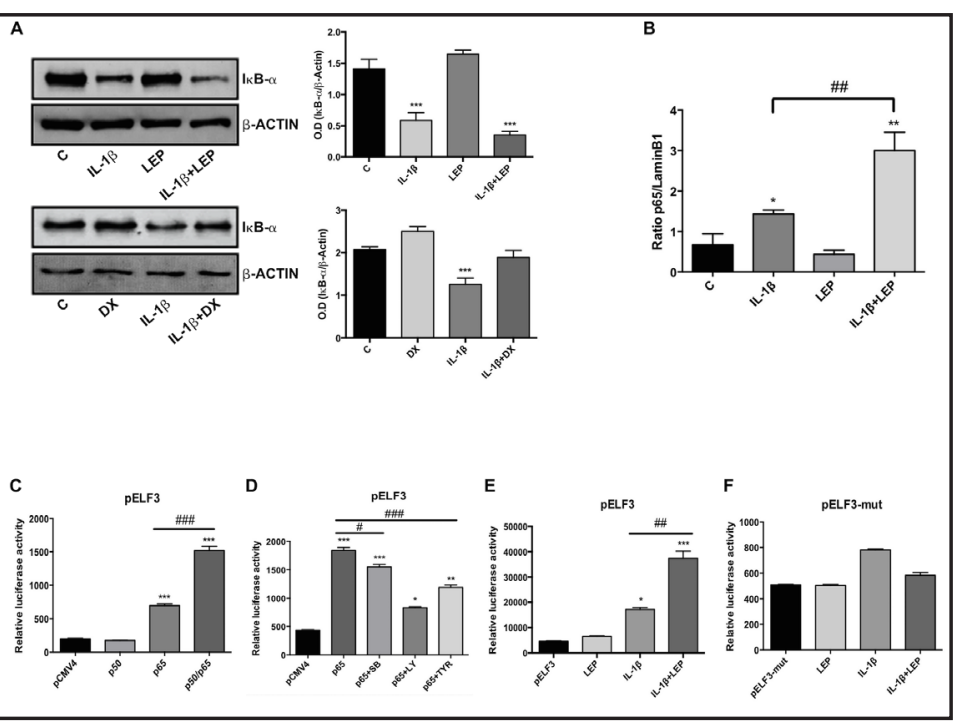
the WT human ELF3 promoter (pELF3) (400 ng) and the expression vectors containing the NF- $\kappa B$ subunits p50 (100 ng) or p65 (100 ng) D. Cells were co-transfected with pELF3 (400 ng) and the expression vector containing the NF- $\mathrm{BB}$ subunit p65 (100 ng) and then treated with the inhibitors LY204002 (10 $\mu \mathrm{M}), \mathrm{SB} 203580(30 \mu \mathrm{M})$ and tyrphostin AG490 $(10 \mu \mathrm{M})$. E. Cells were transfected with Luciferase reporter constructs pELF3 and then treated with IL-1 $\beta$ (10 ng/mL) and leptin (800 nM) for 24 hours. F. Cells were transfected with Luciferase reporter constructs containing the human ELF3 promoter with mutant NF- $\kappa B$-binding sites (pELF3-mut) and treated with IL-1 $\beta$ $(10 \mathrm{ng} / \mathrm{mL})$, leptin $(800 \mathrm{nM})$ alone or together for 24 hours. Luciferase activity was determined 24 hours after transfection. ${ }^{*}$ indicates $\mathrm{p}<0.05$; ${ }^{* *}$ indicates $\mathrm{p}<0.01$; ${ }^{* * *}$ indicates $\mathrm{p}<0.001$ vs control; \# indicates $\mathrm{p}<0.05$; \#\# indicates $\mathrm{p}<0.01$; \#\#\# indicates $\mathrm{p}<0.001$ vs. $\mathrm{p} 65$ or IL-1 $\beta$.

\section{Discussion}

Obesity is associated with several pathologies, including musculoskeletal disorders such as $\mathrm{OA}$, where the increased dysfunctional adiposity increases the incidence and progression KARGER 
of disease [15]. Leptin is the prototype of the adipokine superfamily and it has been proposed as a link between obesity and OA [24]. Leptin levels are higher in the synovial fluids from joints of OA patients than in paired serum samples [25], and the expression of leptin and its functional receptor is strongly up-regulated in human OA cartilage and correlated to the grade of cartilage destruction [26]. In other scenarios, the participation of leptin in the modulation of inflammation and/or immunity has already been demonstrated. In fact, this adipokine has emerged as a factor able to modulate the polarization of CD4+ T cells into $\mathrm{T}_{\mathrm{H}} 1$ and $\mathrm{T}_{\mathrm{H}} 2$ cells $[28,29]$. In addition, leptin also regulates $\mathrm{T}$ regulatory cells proliferation via mTOR, being TReg lymphocytes key cells in the control of the appropriate immune response $[30,31]$. Interestingly, very recently, our group found that leptin can increase the production of pro-inflammatory cytokines such as IL-6, or chemokines such as IL-8 and CC-chemokine3 in CD 4+ T cells from OA patients [32], uncovering also an unexpected immunoregulatory role for leptin also in a non immune cartilage diseases such as osteoarthritis. These last results showed clear evidence for metabolic changes in immune cells in the inflammed osteoarthritic joint contributing to a better understanding of immunometabolic mechanism/s in OA.

The propagation of cytokine-driven stress/inflammatory responses is dependent on the activities of transcription factors that in turn activate multiple downstream genes. ELF3 is among the trans-acting factors that participate in controlling the actions of inflammatory cytokines in articular chondrocytes [12, 14]. In chondrocytes and other cell types, ELF3 controls the promoter activities and gene expression of NOS2, COX2, and MMP13 [9, 10, 14]. Further, ELF3 is a potent repressor of COL2A1 transcription in chondrocytes [12,13], which, together with its activation of MMP13, suggests a fundamental role for this transcription factor in cartilage degeneration and alteration of mechanisms of cartilage repair. We therefore investigated the effects of leptin, alone or in combination with IL-1 $\beta$, on the gene expression and transcriptional activation of ELF3 in human chondrocytes.

One of the most relevant findings arising from this study is that leptin synergizes with IL-1 $\beta$ to induce ELF3 in human chondrocytes. Leptin synergism is dependent on the presence of its functional receptor, since siRNA ablation of LEPR completely blunts leptin activity. As far as we are aware, this is the first report that demonstrates the cooperative interaction between leptin and IL-1 $\beta$ in the induction of ELF3 in human chondrocytes. Synergistic interaction of leptin with IL-1 is not novel and it has been reported in chondrocytes and other cell types, where leptin synergizes with IL-1 to induce NOS2 [27]. However, the signaling and transcriptional events have not been defined completely. Noteworthy, synergistic induction of ELF3 by leptin and IL-1 $\beta$ is intriguingly similar to that observed for the induction of NOS2. Among the potential intracellular signal transduction events, the functional interplay of the JAK2, a leptin receptor-associated tyrosine kinase, PI3K-AKT, and p38 pathways are important for the induction of ELF3 and possibly for the onset as well as the maintenance of the inflammatory response exerted by this transcription factor in cartilage. In line with these results, it was recently described that leptin administration to human articular chondrocytes increased the expression of different ADAMTs, and such effect occurred through the activation of different MAPK such as p38 [20].

Another relevant aspect arising from our study is the dependence of leptin/IL$1 \beta$ synergism on the integrity of NF- $\kappa \mathrm{B}$-dependent ELF3 transcription. NF- $\kappa \mathrm{B}$ has been demonstrated to be involved in the catabolic effects exerted by leptin in $\mathrm{OA}$ and in other rheumatic diseases as rheumatoid arthritis [20,33, 34], so we focused our attention on this transcription factor. In agreement with previous studies [6, 9], our results show that mutation of the proximal NF- $\kappa B$ site in the ELF3 promoter completely abolishes induction by IL-1 $\beta$ and the synergistic induction by leptin and IL-1 $\beta$. Previous findings have shown that NF- $\kappa B$ acts as a key transcription factor in regulating the ELF3-dependent effects of IL-1 on NOS2, COX2, COL2A1, angiopoietin-1, and MMP13 in chondrocytes and other cell types $[9,10,12$, $14]$. In agreement with other studies [35,36], we also found how the anti-inflammatory drug dexamethasone blocked, in part, the activation of NF- $\kappa$ B. Given the relevance of NF- $\kappa B$ in the induction of ELF3 by IL-1 $\beta$ and leptin, it is conceivable that the inhibition of ELF3 expression exerted by dexamethasone occurs via decreased activation of NF- $\kappa$ B.

\section{KARGER}




\section{Cellular Physiology Cell Physiol Biochem 2018;45:2401-2410 \begin{tabular}{c|c|c|} 
DOI: 10.1159/000488227 & O 2018 The Author(s). Published by S. Karger AG, Basel \\
www.karger.com/cpb
\end{tabular} \\ Conde et al.: Leptin Mediates ELF3 in Cartilage, Linking Obesity and Inflammation}

In conclusion, leptin clearly participates in the inflammatory/catabolic response at joint level and the results presented here revealed novel insights of the downstream signaling cascades elicited by leptin.

Our results further support the notion that leptin is a strong pro-inflammatory and pro-catabolic factor, whose downstream actions may be mediated also by ELF3. Our current findings may provide, therefore, new insight and better understanding of the mechanisms underlying the relationship between obesity and OA. They also represent a new starting point for identifying in depth the molecular mechanisms controlling the regulation of gene expression by leptin.

\section{Acknowledgements}

JC and MO participated in acquisition of data, analysis and interpretation of data and critical revision of the manuscript. MS, VA, RG, VL, JP, and MBG participated in acquisition of data and samples, drafting of the manuscript and statistical analysis. AM participated in analysis and interpretation of data and drafting the manuscript. OG participated in conception and design of the study, in analysis and interpretation of data, critical revision of the manuscript and scientific supervision of experiments.

OG is Staff Personnel of Xunta de Galicia (Servizo Galego de Saude, SERGAS) through a research-staffstabilization contract (ISCIII/SERGAS). JC and MS are "Sara Borrell" Researchers funded by ISCIII and FEDER. RG is a "Miguel Servet" Researcher funded by Instituto de Salud Carlos III (ISCIII) and FEDER. OG and RG are members of RETICS Programme, RD16/0012/0014 (RIER: Red de Investigación en Inflamación y Enfermedades Reumáticas) via Instituto de Salud Carlos III (ISCIII) and FEDER. The work of OG (PIE13/00024 and PI14/00016 and PI17/00409), and RG (PI16/01870 and CP15/00007) was funded by Instituto de Salud Carlos III and FEDER. OG is beneficiary of the project funded by Research Executive Agency of the European Union in the framework of MSCA-RISE Action of the H2020 Programme. Support was also provided by National Institutes of Health grants R01AG022021, R21-AR054887, and RC4 AR060546 (to MBG) and R21-AG049980 (to M0). The funders had no role in study design, data collection, and analysis, decision to publish, or preparation of the manuscript.

\section{Disclosure Statement}

The authors declare no conflict of interests.

\section{References}

1 Hunter DJ, Felson DT: Osteoarthritis. BMJ 2006;332:639-642.

12 Felson DT: Relation of obesity and of vocational and avocational risk factors to osteoarthritis. J Rheumatol 2005;32:1133-1135.

-3 Berenbaum F: Osteoarthritis as an inflammatory disease (osteoarthritis is not osteoarthrosis!). Osteoarthritis Cartilage 2013;21:16-21.

4 Goldring MB, Otero M, Plumb DA, Dragomir C, Favero M, El Hachem K, Hashimoto K, Roach HI, Olivotto E, Borzi RM, Marcu KB, Borzì RM, Marcu KB: Roles of inflammatory and anabolic cytokines in cartilage metabolism: signals and multiple effectors converge upon MMP-13 regulation in osteoarthritis. Eur Cell Mater 2011;21:202-220.

-5 Otero M, Gomez Reino JJ, Gualillo 0: Synergistic induction of nitric oxide synthase type II: in vitro effect of leptin and interferon-gamma in human chondrocytes and ATDC5 chondrogenic cells. Arthritis Rheum 2003;48:404-409. 


\section{Cellular Physiology Cell Physiol Biochem 2018;45:2401-2410

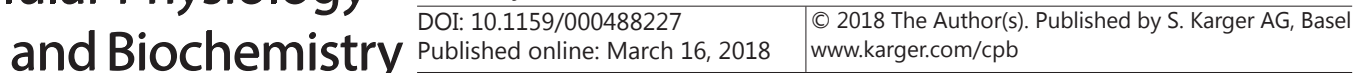 \\ Conde et al.: Leptin Mediates ELF3 in Cartilage, Linking Obesity and Inflammation}

6 Grall F, Gu X, Tan L, Cho JY, Inan MS, Pettit AR, Thamrongsak U, Choy BK, Manning C, Akbarali Y, Zerbini L, Rudders S, Goldring SR, Gravallese EM, Oettgen P, Goldring MB, Libermann TA: Responses to the proinflammatory cytokines interleukin-1 and tumor necrosis factor alpha in cells derived from rheumatoid synovium and other joint tissues involve nuclear factor kappaB-mediated induction of the Ets transcription factor ESE-1. Arthritis Rheum 2003;48:1249-1260.

7 Hirata M, Kugimiya F, Fukai A, Saito T, Yano F, Ikeda T, Mabuchi A, Sapkota BR, Akune T, Nishida N, Yoshimura N, Nakagawa T, Tokunaga K, Nakamura K, Chung U, Kawaguchi H: C/EBP $\beta$ and RUNX2 cooperate to degrade cartilage with MMP-13 as the target and HIF- $2 \alpha$ as the inducer in chondrocytes. Hum Mol Genet 2012;21:1111-1123.

-8 Oettgen P, Alani RM, Barcinski MA, Brown L, Akbarali Y, Boltax J, Kunsch C, Munger K, Libermann TA: Isolation and characterization of a novel epithelium-specific transcription factor, ESE-1, a member of the ets family. Mol Cell Biol 1997;17:4419-4433.

-9 Rudders S, Gaspar J, Madore R, Voland C, Grall F, Patel A, Pellacani A, Perrella MA, Libermann TA, Oettgen P: ESE-1 is a novel transcriptional mediator of inflammation that interacts with NF-kappa B to regulate the inducible nitric-oxide synthase gene. J Biol Chem 2001;276:3302-3309.

10 Grall FT, Prall WC, Wei W, Gu X, Cho JY, Choy BK, Zerbini LF, Inan MS, Goldring SR, Gravallese EM, Goldring MB, Oettgen P, Libermann TA: The Ets transcription factor ESE-1 mediates induction of the COX-2 gene by LPS in monocytes. FEBS J 2005;272:1676-1687.

11 Conde J, Otero M, Scotece M, Abella V, López V, Pino J, Gómez R, Lago F, Goldring MB, Gualillo O: E74-like factor 3 and nuclear factor- $\kappa B$ regulate lipocalin-2 expression in chondrocytes. J Physiol 2016;594:61336146.

12 Peng H, Tan L, Osaki M, Zhan Y, Ijiri K, Tsuchimochi K, Otero M, Wang H, Choy BK, Grall FT, Gu X, Libermann TA, Oettgen P, Goldring MB: ESE-1 is a potent repressor of type II collagen gene (COL2A1) transcription in human chondrocytes. J Cell Physiol 2008;215:562-573.

-13 Otero M, Peng H, Hachem K El, Culley KL, Wondimu EB, Quinn J, Asahara H, Tsuchimochi K, Hashimoto K, Goldring MB: ELF3 modulates type II collagen gene ( COL2A1) transcription in chondrocytes by inhibiting SOX9-CBP/p300-driven histone acetyltransferase activity. Connect Tissue Res 2017;58:15-26.

14 Otero M, Plumb DA, Tsuchimochi K, Dragomir CL, Hashimoto K, Peng H, Olivotto E, Bevilacqua M, Tan L, Yang Z, Zhan Y, Oettgen P, Li Y, Marcu KB, Goldring MB: E74-like factor 3 (ELF3) impacts on matrix metalloproteinase 13 (MMP13) transcriptional control in articular chondrocytes under proinflammatory stress. J Biol Chem 2012;287:3559-3572.

15 Conde J, Scotece M, López V, Gómez R, Lago F, Pino J, Gómez-Reino JJ, Gualillo O: Adipokines: novel players in rheumatic diseases. Discov Med 2013;15:73-83.

16 Lago R, Gomez R, Otero M, Lago F, Gallego R, Dieguez C, Gomez-Reino JJ, Gualillo O: A new player in cartilage homeostasis: adiponectin induces nitric oxide synthase type II and pro-inflammatory cytokines in chondrocytes. Osteoarthritis Cartilage 2008;16:1101-1109.

17 Gómez R, Scotece M, Conde J, Gómez-Reino JJ, Lago F, Gualillo O: Adiponectin and leptin increase IL-8 production in human chondrocytes. Ann Rheum Dis 2011;70:2052-2054.

18 Koskinen A, Vuolteenaho K, Nieminen R, Moilanen T, Moilanen E: Leptin enhances MMP-1, MMP-3 and MMP-13 production in human osteoarthritic cartilage and correlates with MMP-1 and MMP-3 in synovial fluid from OA patients. Clin Exp Rheumatol [cited 2013 Jul 17];29:57-64.

19 Conde J, Scotece M, López V, Gómez R, Lago F, Pino J, Gómez-Reino JJ, Gualillo O: Adiponectin and leptin induce VCAM-1 expression in human and murine chondrocytes. PLoS One 2012;7:e52533.

-20 Yaykasli KO, Hatipoglu OF, Yaykasli E, Yildirim K, Kaya E, Ozsahin M, Uslu M, Gunduz E: Leptin induces ADAMTS-4, ADAMTS-5, and ADAMTS-9 genes expression by mitogen-activated protein kinases and NF-kB signaling pathways in human chondrocytes. Cell Biol Int 2015;39:104-12.

21 Goldring MB, Birkhead JR, Suen LF, Yamin R, Mizuno S, Glowacki J, Arbiser JL, Apperley JF: Interleukin-1 beta-modulated gene expression in immortalized human chondrocytes. J Clin Invest 1994;94:2307-2316.

22 Santoro A, Conde J, Scotece M, Abella V, López V, Pino J, Gómez R, Gómez-Reino JJ, Gualillo O: Choosing the right chondrocyte cell line: Focus on nitric oxide. J Orthop Res 2015;33:1784-1788.

23 Conde J, Scotece M, Abella V, Lois A, López V, García-Caballero T, Pino J, Gómez-Reino JJ, Gómez R, Lago F, Gualillo O: IL-36 $\alpha$ : a novel cytokine involved in the catabolic and inflammatory response in chondrocytes. Sci Rep 2015;5:16674. 


\section{Cellular Physiology Cell Physiol Biochem 2018;45:2401-2410

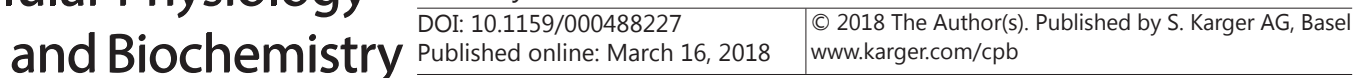 \\ Conde et al.: Leptin Mediates ELF3 in Cartilage, Linking Obesity and Inflammation}

24 Scotece M, Conde J, Lopez V, Lago F, Pino J, Gomez-Reino JJ, Gualillo O: Leptin in joint and bone diseases: new insights. Curr Med Chem 2013;20:3416-3425.

-25 Presle N, Pottie P, Dumond H, Guillaume C, Lapicque F, Pallu S, Mainard D, Netter P, Terlain B: Differential distribution of adipokines between serum and synovial fluid in patients with osteoarthritis. Contribution of joint tissues to their articular production. Osteoarthr Cartil 2006;14:690-695.

26 Simopoulou T, Malizos KN, Iliopoulos D, Stefanou N, Papatheodorou L, Ioannou M, Tsezou A: Differential expression of leptin and leptin's receptor isoform (Ob-Rb) mRNA between advanced and minimally affected osteoarthritic cartilage; effect on cartilage metabolism. Osteoarthr Cartil 2007;15:872-883.

-27 Otero M, Lago R, Lago F, Reino JJG, Gualillo O: Signalling pathway involved in nitric oxide synthase type II activation in chondrocytes: synergistic effect of leptin with interleukin-1. Arthritis Res Ther 2005;7:R581591.

28 Batra A, Okur B, Glauben R, Erben U, Ihbe J, Stroh T, Fedke I, Chang H-D, Zeitz M, Siegmund B: Leptin: a critical regulator of CD4+ T-cell polarization in vitro and in vivo. Endocrinology 2010;151:56-62.

29 Kim SY, Lim JH, Choi SW, Kim M, Kim S-T, Kim M-S, Cho YS, Chun E, Lee K-Y: Preferential effects of leptin on CD4 T cells in central and peripheral immune system are critically linked to the expression of leptin receptor. Biochem Biophys Res Commun 2010;394:562-568.

30 Matarese G, Procaccini C, De Rosa V, Horvath TL, La Cava A: Regulatory T cells in obesity: the leptin connection. Trends Mol Med 2010;16:247-256.

-31 Procaccini C, De Rosa V, Galgani M, Carbone F, Cassano S, Greco D, Qian K, Auvinen P, Calì G, Stallone G, Formisano L, La Cava A, Matarese G: Leptin-induced mTOR activation defines a specific molecular and transcriptional signature controlling CD4+ effector T cell responses. J Immunol 2012;189:2941-2953.

-32 Scotece M, Pérez T, Conde J, Abella V, López V, Pino J, Gonzalez-Gay MA, Gomez-Reino JJ, Mera A, Gomez R, Gualillo 0: Adipokines induce pro-inflammatory factors in activated Cd4+ T cells from osteoarthritis patient. J Orthop Res 2017;35:1299-1303.

-33 Hui W, Litherland GJ, Elias MS, Kitson GI, Cawston TE, Rowan AD, Young DA: Leptin produced by joint white adipose tissue induces cartilage degradation via upregulation and activation of matrix metalloproteinases. Ann Rheum Dis 2012;71:455-462.

-34 Tong K-M, Shieh D-C, Chen C-P, Tzeng C-Y, Wang S-P, Huang K-C, Chiu Y-C, Fong Y-C, Tang C-H: Leptin induces IL-8 expression via leptin receptor, IRS-1, PI3K, Akt cascade and promotion of NF-kappaB/p300 binding in human synovial fibroblasts. Cell Signal 2008;20:1478-1488.

-35 Antonelli A, Bianchi M, Crinelli R, Gentilini L, Magnani M: Modulation of ICAM-1 expression in ECV304 cells by macrophage-released cytokines. Blood Cells Mol Dis 2001 27:978-991.

-36 Ing NH, Forrest DW, Riggs PK, Loux S, Love CC, Brinsko SP, Varner DD, Welsh TH: Dexamethasone acutely down-regulates genes involved in steroidogenesis in stallion testes. J Steroid Biochem Mol Biol 2014;143:451-459. 